3. Воробьев, А.В. Земельные ресурсы Волгоградской области и их оценка./ ООО «Издательство Волгоград», 2006 - 44c.

4. Воробьев А.В. Некоторые вопросы землеустроительного обеспечения органов местного самоуправления Волгоградской области (статья) / А.В. Воробьев, М.О. Колобова // Материалы Международной научно-практической конференции. Том 1 - Волгоград: ФГБОУ ВПО Волгоградский ГАУ, 2012.- С.323-327

5. Воробьев А.В. Колобова М.О. «Современные проблемы землеустройства и кадастров» - Волгоград: ФГБОУ ВПО Волгоградский ГАУ, ИПК «Нива», 2013.- 36 с.

6. Воробьев А.В. Влияние некоторых показателей качественной характеристики земель на формирование структуры сельскохозяйственных угодий в регионе / Материалы международной научно-практической конференции, г. Волгоград. Том 4.- Волгоград: ФГБОУ ВПО Волгоградский ГАУ, 2014 C. $291-295$

7. Воробьев А.В. Земельная реформа в Волгоградской области»: монография / А.В. Воробьев. Волгоград: ФГБОУ ВПО Волгоградский ГАУ, ИПК «Нива», 2014.- 164 с.

8. Воробьев А.В. Проблемы оптимизации площади пахотных земель в регионе / А.В. Воробьев, М.О. Колобова // Материалы международной научно-практической конференции, 12 -14 ноября 2014 г., г. Волгоград. Том 1.- Волгоград: ФГБОУ ВПО Волгоградский ГАУ, 2015. - С. 318 - 322

9. Воробьев А.В. Совершенствование системы земельного учета при проведении государственной кадастровой оценки земель сельскохозяйственного назначения в Волгоградской области / А.В. Воробьев, А.В. Смыков // «Известия» Нижне-Волжского Агроуниверситетского комплекса: «Наука и высшее профессиональное образование» № 3(39) 2015 г.

10. Волгоградская областьв цифрах.2015: краткий сб./Терр.органФед.службы гос. статистики по Волгогоград. обл. - Волгоград: Волгоградстаст, 2016. - 376 с.

11. Воробьев А.ВФормирование территорий муниципальных образований: учебное пособие / А.В.Воробьев, А.Д. Ахмедов. - Волгоград: ФГБОУ ВО Волгоградский ГАУ, 2017 - 128 с.

\title{
Кашутина Е.В. \\ Инновационная деятельность Лазаревской опытной станции в области биологической защиты растений
}

Лазаревская опытная станщия защчиты растений (Россия, Сочи)

doi: $10.18411 / 1 j-31-08-2017-33$

idsp: 000001:lj-31-08-2017-33

\section{Аннотация}

В настоящей работе представлены результаты инновационной деятельности Лазаревской опытной станции в области биологической защиты растений. Учреждение в течение последних лет предоставляет своевременное консультационно-методическое обеспечение производителей сельхозпродукции рекомендациями по экологизации защиты растений. Разработки научных сотрудников лабораторий Лазаревской опытной станции имеют важное значение для социально-экономического развития курортного региона г. Сочи по защите зеленых насаждений экологически безопасными методами.

Ключевые слова: инновационная деятельность, АПК, экологически безопасная защита растений, консультационно-методическое сопровождение, научноисследовательская работа.

Опыт развитых стран мира убедительно показывает, что повышение эффективности агропромышленного производства достигается преимущественно за счет активизации инновационной деятельности, то есть успешного функционирования научнотехнической сферы отрасли. Конечным результатом инновационной деятельности является создание инноваций и их освоение непосредственно в производстве, что способствует систематическому организационно-экономическому, техническому и технологическому обновлению агропромышленного производства (АПК), повышению его эффективности. 
Инновации в АПК - это новые технологии, новая техника, новые сорта растений, новые удобрения и средства защиты растений, новые методы профилактики и лечения животных, новые формы организации, финансирования и кредитования производства, новые подходы к подготовке, переподготовке и повышению квалификации кадров и т. д.

Исследования показывают, что освоение инноваций в производстве способствует поддержанию определенного производственного уровня, сопровождается расширением воспроизводства, устойчивостью получения доходов товаропроизводителями. Мировая практика свидетельствует, что решающим условием ускорения научно-технического прогресса является развитие инновационной деятельности в АПК, как совокупности последовательно осуществляемых мероприятий по организации исследований и созданию инноваций с последующим освоением их непосредственно в производстве в целях создания новой или улучшенной продукции, новой или усовершенствованной технологии ее производства. [1]

Инновационный процесс поощряется и регулируется государством, путем создания и реализации инновационной политики, которая является частью государственной аграрной политики, так как в числе ее современных приоритетов наряду с экономическими, инвестиционными, институциональными важное значение должно уделяться инновационным приоритетам.

Инновационная деятельность Лазаревской опытной станции защиты растений осуществляется в рамках Программы фундаментальных исследований государственных академий наук на 2013-2020 годы, утвержденной Правительством Российской Федерации 3 декабря 2012 г. № 2237-р, по направлениям:

- Разработка технологий пополнения, хранения и поддержания биоагентов Государственной коллекции энтомофагов и энтомопатогенов с целью создания биологических средств защиты растений.

- Разработка способов применения паразитов, хищников и микроорганизмов в борьбе с вредителями и болезнями сельскохозяйственных и декоративных культур защищенного и открытого грунта (интродукция, акклиматизация, селекция, внутриареальное расселение, сезонная колонизация, содействие деятельности энтомофагов), определение эффективности новых биопрепаратов и энтомофагов против важнейших вредителей и болезней сельскохозяйственных и декоративных культур защищенного и открытого грунта.

- Разработка методов массового разведения энтомоакарифагов вредителей сельскохозяйственных и декоративных культур защищенного и открытого грунта для целей биометода.

Научные исследования требуют ежегодного масштабного финансирования и всесторонней государственной поддержки, поскольку от этого зависит научный уровень и качество инноваций.

Инновационный процесс в сельском хозяйстве имеет ряд особенностей по сравнению с другими сферами хозяйствования, а именно:

- длительный процесс разработки инновации (связано с селекционной работой);

- инновации носят улучшающий характер (связано с их ориентацией на повышение урожайности, производительности объекта);

- исследование живых организмов (растений, животных, микроорганизмов);

- ведущая роль научно-исследовательских учреждений;

- зависимость от природной зоны и климатических условий. [2]

Поэтому можно выделить три основных направлений внедрения инноваций в деятельность сельскохозяйственных предприятий: 
1) инновации в сфере человеческого фактора - подготовка специалистов, способных осваивать и использовать в производстве новую технику, оборудование и технологии, повышение квалификации сотрудников предприятия и их переподготовка;

2) инновации в сфере биологического фактора - разработка и освоение нововведений, обеспечивающих повышение плодородия земель сельскохозяйственного назначения, рост продуктивности животных и урожайности сельскохозяйственных культур;

3) инновации в сфере техногенного фактора - обеспечивают совершенствование технического и технологического потенциала сельскохозяйственного предприятия.

Внедрение и рыночное освоение инноваций сдерживается рядом факторов, среди которых важнейшими являются низкая платежеспособность хозяйств, отсутствие достоверной и полной информации о новейших отечественных научных разработках в области сельского хозяйства [3].

Инновационная деятельность опытной станции обеспечивает: внедрение новейших инновационных разработок систем защиты сельскохозяйственных и декоративных культур, охрану, передачу и приобретение прав на объекты интеллектуальной собственности Лазаревской опытной станции. С целью своевременного информационноконсультационного обеспечения АПК разработан с использованием современных информационных и телекоммуникационных технологий и регулярно обновляется официальный сайт учреждения (Лазаревская-ОСЗР.рф), освещающий перечень предоставляемых станцией услуг, внедрение технологий и разработок, результаты фитосанитарного мониторинга агроэкосистем г. Сочи.

Лазаревская опытная станция защиты растений в течение последних лет эффективно сотрудничает с: ООО Сельскохозяйственная фирма «Верлиока», ООО «Инновационный центр защиты растений», Зоологический институт РАН, ООО «Инновационный центр Энтомопротект», ООО «Ист инвестментс», санаторнокурортными учреждениями Лазаревского района г. Сочи, ФГБНУ ВНИИЦиСК, ФГБНУ «ВНИИП им. К.И.Скрябина».

Важным показателем инновационной научно-исследовательской работы Лазаревской опытной станции является защита авторских прав объектов интеллектуальной собственности, к которым относятся новейшие инновационные разработки сотрудников станции. Для защиты научных приоритетов на станции ведется большая работа по выявлению патентоспособных решений и оформлению их заявками в Федеральный институт промышленной собственности. В 2011-2016 годах получено 10 патентов РФ на изобретения, используемые для массового производства , транспортировки полезных энтомофагов и фитосанитарного мониторинга агробиоценозов г. Сочи.

Благодаря многолетним исследованиям на Лазаревской опытной станции разработаны апробированы и внедрены в сельскохозяйственное производство:

- Технология защиты от вредных кокцид с/х и декоративных культур,

- Технология производства энтомофагов для защиты с/х культур,

- Технологии производства криптолемуса, хармонии на искусственных питательных средах,

- Технология биологической защиты декоративных культур от комплекса тлей. $[4,5,6,7]$ :

С 2013 г. ежегодно осуществляется консультационно-методическое сопровождение процесса организации и успешного функционирования биолабораторий массового разведения полезных энтомофагов в тепличном комбинате ООО Сельскохозяйственная фирма «Верлиока» г. Сочи, с использованием разработанных на станции технологий и рекомендаций по массовому разведению и применению энтомофагов. 
На официальном сайте станции (Лазаревская-ОСЗР.рф) регулярно освещаются результаты мониторинга агроэкосистем Черноморского побережья, факты выявления опасных вредителей и болезней культур открытого и защищенного грунта с целью своевременного принятия мер по их защите руководителями санаторно-курортных учреждений.

Усовершенствованные технологии массового разведения и применения полезных энтомофагов для борьбы с вредителями овощных и декоративных культур ежегодно освещаются в методических рекомендациях, информационных листах.

Применение технологий биологической защиты растений способствует увеличению урожайности и повышению качества сельскохозяйственной продукции.

С целью сохранения жизнеспособности применяемых энтомофагов применяются разработанные на протяжении 2014-2016г.г. контейнеры для транспортировки. [8,9]

В настоящее время в арсенале биометода имеются высокоэффективные, экономичные и экологически безопасные биологические средства. В рамках научнотехнического сотрудничества с ведущими научно-исследовательскими институтами, Лазаревская опытная станция совместно с ФГБНУ ВИЗР ведет научно-исследовательские работы по выявлению, идентификации и применению аборигенных штаммов энтомопатогенных грибов; с сотрудниками ФГБНУ Зоологический институт СанктПетербурга РАН продолжаются исследования по изучению экономически важных паразитических перепончатокрылых насекомых фауны Краснодарского края.

Научных сотрудников Лазаревской опытной станции Сочинский национальный парк приглашает к оценке уровня, качества и актуальности работ учащихся учебных учреждений г. Сочи по направлениям экологической защиты агроэкосистем Черноморского побережья.

Для информационного обеспечения плодотворной научно-исследовательской, производственной работы в области экологически безопасной защиты сельскохозяйственных и декоративных культур открытого и защищенного грунта, осуществления прямого взаимодействия с потребителями продукции и услуг сотрудники станции принимают участие в работе Международных и Всероссийских конференций [10-15].

Информационно-консультационное обеспечение производителей овощной, цитрусовой продукции защищенного грунта, цветочно-декоративной продукции открытого грунта субъектов Российской Федерации позволяет заинтересовать товаропроизводителей результатами научно-исследовательских работ ученых; внедрять инновационные разработки и технологии в производство, повышать экономические показатели хозяйствующих субъектов и поднимать спрос российского потребителя на продукты отечественного производства.

Следует отметить, что основные экономические и внутренние факторы, сдерживающие инновации - это недостаток собственных денежных средств, высокая стоимость нововведений, высокий экономический риск. Финансовая поддержка инновационной деятельности необходима на всех этапах инновационного процесса, поскольку стимулирование внедрения изобретений должно обеспечить спрос на отечественные научные разработки и обеспечить импортозамещение товаров в аграрном секторе, услуг в области биологической защиты растений.

$$
* * *
$$

1. Инновационная деятельность в агропромышленном комплексе России. Коллективная монография. Под редакцией И.Г. Ушачева, Е.С. Оглоблина, И.С. Санду, А.И. Трубилина. - М.: “Экономика и информатика", 2006. - 374 с.

2. Баранова О.А., Тусков А.А. СИСТЕМА ГОСУДАРСТВЕННОГО СТИМУЛИРОВАНИЯ ИННОВАЦИОННОЙ ДЕЯТЕЛЬНОСТИ В АПК // СовременНЫе ПроблемЫ науки и образования. 2012. - № 6. 
3. Бугара А.Н. Инновационный потенциал предприятий аграрного сектора сельских территорий // Управление инновациями: теория, методология, практика: сборник материалов XV Международной научно-практической конференции. - Новосибирск: ЦРНС, 2016. - С. 96-99.

4. Пат. 2485788 Российская Федерация, МПК А23К 1/00. Способ производства питательной среды для разведения личинок хищного жука криптолемуса Cryptolaemus montrouzieri Muls. [Текст] / Бугаева Л.Н., Кашутина Е.В., Кашутин Е.Н., Слободянюк Г.А., Широбокова И.М.; заявитель и патентообладатель Гос. науч. учрежд. Лазаревская опытная станция защиты растений Всероссийского науч.-исслед. ин-та биол. защиты раст. РАСХН. № 2011127858/10; заявл. 06.07.2011; опубл. 27.06.13, Бюл. № $18-6$ c.

5. Пат. 2485770 Российская Федерация, МПК А23К 67/033. Способ разведения хищного жука криптолемуса Cryptolaemus montrouzieri Muls. [Текст] / Бугаева Л.Н., Кашутина Е.В., Кашутин Е.Н., Хейшхо И. В., Морозова Л.В.; заявитель и патентообладатель Гос. науч. учрежд. Лазаревская опытная станция защиты растений Всероссийского науч.-исслед. ин-та биол. защиты раст. РАСХН. № $2011127765 / 10$; заявл. 06.07.2011; опубл. 27.06.13, Бюл. № 18 - 5 с.

6. Пат. 2515688 Российская Федерация, МПК А23К 1/18 (2006.01) А01К 67/033 (2006.01). Способ производства питательной среды для разведения кокцинеллиды Harmonia axiridis Pall. [Текст] / Кашутина Е.В., Слободянюк Г.А., Игнатьева Т. Н., Ясюк Л.В.; заявитель и патентообладатель Гос. науч. учрежд. Лазаревская опытная станция защиты растений Всероссийского науч.-исслед. ин-та биол. защиты раст. РАСХН. № 2012143921/13; заявл. 15.10.2012; опубл. 20.05.14, Бюл. № 14 - 5 с.

7. Пат. 2520860 Российская Федерация, МПК С12N1/00 (2006.01) А01K67/033 (2006.01) Способ разведения кокцинеллиды Harmonia axiridis Pall. [Текст] / Бугаева Л.Н., Кашутина Е. В., Кашутин Е.Н., Слободянюк Г.А. Хейшхо И.В., Игнатьева Т. Н., Морозова Л.В.; заявитель и патентообладатель Гос. науч. учрежд. Лазаревская опытная станция защиты растений Всероссийского науч.-исслед. ин-та биол. защиты раст. РАСХН. 2012143922/10; заявл., 15.10.2012; опубл. 20.04.14, Бюл. №18 - 5 с.

8. Пат. 144500 Российская Федерация, МПК B65D85/50 (2006.01). Контейнер для транспортировки насекомых. [Текст] / Кашутина Е. В., Андреенко О.Н., Хетагурова Е.В., Маркарян М.А.; заявитель и патентообладатель Гос. науч. учрежд. Лазаревская опытная станция защиты растений Всероссийского науч.-исслед. ин-та биол. защиты раст. № 2014116141/12; заявл. 22.04.2014; опубл. 20.08.2014, Бюл. № $23-1$ с.: ил.

9. Пат. 160972 Российская Федерация, МПК B65D85/50 (2006.01). Контейнер для транспортировки насекомых на растениях. [Текст] / Кашутина Е. В., Игнатьева Т.Н., Бугаев В.В., Андреенко О.Н., заявитель и патентообладатель Гос. науч. учрежд. Лазаревская опытная станция защиты растений Всероссийского науч.-исслед. ин-та биол. защиты раст. № 2015126207/12; заявл. 30.06.2015; опубл. 10.04.2016, Бюл. № $10-2$ с.: ил.

10. Бугаева Л.Н., Игнатьева Т.Н., Кашутина Е.В. Самшитовая огневка - причина экологического бедствия. // Вестник защиты растений. - СПб. Вып. 4(86). 2015г. С.52-53.

11. Бугаева Л.Н., Кашутина Е.В., Слободянюк Г.А., Игнатьева Т.Н. Результаты многолетних исследований эффективности криптолемуса - энтомофага вредителей сельскохозяйственных и декоративных культур // Субтропическое и декоративное садоводство: сб. науч. тр. ФГБНУ ВНИИЦиСК - Сочи: ФГБНУ ВНИИЦСК, 2015. - Вып.53. С. 133-141.

12. Кашутина Е.В. Энтомофаги и энтомопатогены в биологическом методе защиты цветочнодекоративных культур // Субтропическое и декоративное садоводство: сб. науч. тр. ФГБНУ ВНИИЦиСК - Сочи: ФГБНУ ВНИИЦСК, 2014. - Вып.50. С. 251-257.

13. Кашутина Е.В. Информационно-консультационное обеспечение АПК // Сб.: 9-Я Межденародная научно-практическая конференция "Биологическая защита растений - основа стабилизации агроэкосистем" с молодежной стратегической сессией "Кадры, ресурсы, возможности, инновации" Краснодар, 20-22 сентября 2016 г. / Изд. ВНИИБЗР, Краснодар, 2016. - С. 50-55.

14. Слободянюк Г.А., Игнатьева Т.Н., Кашутина Е.В., Андреенко О.Н. Самшитовая огневка (Суdalima perspectalis Walker) - опасный вредитель самшита // Сборник «Биологическая защита растений основа стабилизации экосистем». - Краснодар: ВНИИБЗР, 16-18 сент. 2014, с.201-204.

15. Слободянюк Г.А., Кашутина Е.В., Ясюк Л.В. Технология разведения энтомофагов на искусственных питательных средах // Субтропическое и декоративное садоводство: сб. науч. тр. ФГБНУ ВНИИЦиСК. - Сочи: ФГБНУ ВНИИЦСК, 2015. - Вып.53. -с.153-157 